\title{
Inactivation of Foodborne Bacteria Biofilms by Aqueous and Gaseous Ozone
}

\author{
Marilena Marino, Michela Maifreni*, Anna Baggio and Nadia Innocente \\ Dipartimento di Scienze Agroalimentari, Ambientali e Animali, Università degli Studi di Udine, Udine, Italy
}

In this study, the efficacy of treatments with ozone in water and gaseous ozone against attached cells and microbial biofilms of three foodborne species, Pseudomonas fluorescens, Staphylococcus aureus, and Listeria monocytogenes, was investigated. Biofilms formed on AISI 304 stainless steel coupons from a mixture of three strains (one reference and two wild strains) of each microbial species were subjected to three types of treatment for increasing times: (i) ozonized water (0.5 ppm) by immersion in static condition, (ii) ozonized water under flow conditions, and (iii) gaseous ozone at different concentrations (0.1-20 ppm). The Excel add-in GinaFit tool allowed to estimate the survival curves of attached cells and microbial biofilms, highlighting that, regardless of the treatment, the antimicrobial effect occurred in the first minutes of treatment, while by increasing contact times probably the residual biofilm population acquired greater resistance to ozonation. Treatment with aqueous ozone under static conditions

Edited by:

Eugenia Bezirtzoglou, Democritus University of Thrace,

Greece

Reviewed by:

Birce Mercanoglu Taban,

Ankara University, Turkey

Tim Maisch

University of Regensburg, Germany

*Correspondence:

Michela Maifreni

michela.maifreni@uniud.it

Specialty section:

This article was submitted to

Food Microbiology,

a section of the journal

Frontiers in Microbiology

Received: 07 June 2018

Accepted: 09 August 2018

Published: 28 August 2018

Citation:

Marino M, Maifreni M, Baggio A and Innocente N (2018) Inactivation of Foodborne Bacteria Biofilms by Aqueous and Gaseous Ozone.

Front. Microbiol. 9:2024. doi: 10.3389/fmicb.2018.02024 resulted in an estimated viability reduction of 1.61-2.14 Log CFU/ $\mathrm{cm}^{2}$ after $20 \mathrm{~min}$, while reduction values were higher $\left(3.26-5.23 \mathrm{Log} \mathrm{CFU} / \mathrm{cm}^{2}\right)$ for biofilms treated in dynamic conditions. S. aureus was the most sensitive species to aqueous ozone under dynamic conditions. With regard to the use of gaseous ozone, at low concentrations (up to $0.2 \mathrm{ppm}$ ), estimated inactivations of 2.01-2.46 Log CFU/ $\mathrm{cm}^{2}$ were obtained after $60 \mathrm{~min}$, while at the highest concentrations a complete inactivation $\left(<10 \mathrm{CFU} / \mathrm{cm}^{2}\right)$ of the biofilms of $L$. monocytogenes and the reduction of 5.51 and $4.72 \mathrm{Log} \mathrm{CFU} / \mathrm{cm}^{2}$ of $P$. fluorescens and $S$. aureus respectively after 60 and 20 min were achieved. Considering the results, ozone in water form might be used in daily sanitation protocols at the end of the day or during process downtime, while gaseous ozone might be used for the treatment of confined spaces for longer times (e.g., overnight) and in the absence of personnel, to allow an eco-friendly control of microbial biofilms and consequently reduce the risk of cross-contamination in the food industry.

Keywords: ozone, microbial biofilms, stainless steel, Listeria monocytogenes, Pseudomonas fluorescens, Staphylococcus aureus

\section{INTRODUCTION}

Infectious diseases induced by microorganisms are increasing in frequency worldwide and are one of the main illness causes all over the world. According to the latest report of the European Centre for Disease Prevention and Control, 1.1 million cases of notifiable infectious diseases were accounted in the EU in 2014 (ECDC, 2016). Despite the enormous advancement in processing 
technologies to assure food safety, contaminated food and water still continue to cause infectious diseases worldwide, and this is not just an underdeveloped world problem. For example, in Europe, in 2016, foodborne outbreaks (including waterborne outbreaks) caused 49,950 illnesses, 3,869 hospitalizations and 20 deaths (EFSA, 2017). As well as causing foodborne diseases, microorganisms can lead to significant economic losses due to spoilage both at the primary production level and the retail. In fact, the increased attention on food safety in the past decades has decreased the focus on the damage of food through spoilage, particularly in developed countries where food is abundant. It has been estimated that approximately 1.3 billion tons of food is lost or wasted globally per year, and microbial spoilage is one of the main causes of food loss or wastes worldwide along the entire food supply chain (Bräutigam et al., 2014; Thyberg and Tonjes, 2016).

The hygienic condition of surfaces and equipment used for food processing has a significant influence on the presence of microbial pathogens and spoilers in food products. If cleaning and sanitizing processes are not performed in the correct manner, residues of organic and inorganic substances could remain and create a suitable environment for biofilm development. Biofilms are made of microorganisms adhered to and growing on a surface and are a prevalent mode of growth for microorganisms: in this form, they are enclosed in extracellular polymeric substances (EPS) which protect cells against adverse environmental conditions, especially antimicrobials. Several food spoilage and pathogenic bacteria have been reported to attach and form biofilms on different food contact surfaces, and biofilms have become challenging in a wide range of food industries, such as dairy plants (Stellato et al., 2015), fish and seafood processing areas (Takahashi et al., 2009), meat and poultry processing (Liu et al., 2015), catering establishments (Marino et al., 2011) as well as fermented beverages plants (Maifreni et al., 2015). Major food pathogens, such as Listeria monocytogenes, Staphylococcus aureus, and Escherichia coli, can form biofilms and so become a significant threat to consumers' health (Dourou et al., 2011; Ferreira et al., 2014). It has been demonstrated that the colonization of surfaces by microbial pathogens can lead to outbreaks linked to the consumption of fresh produce (Beuchat, 2002).

Conventional strategies to control biofilms are currently based on chemical disinfection. However, these methods are not always efficient and ecologically friendly. In fact, it has been showed that during routinary sanitization procedures bacteria can become less sensitive or even resistant to an antimicrobial compound following intermittent or continuous exposure to sub-lethal concentrations (To et al., 2002). Moreover, there are a lot of environmental and human health concerns related to the use of chemical sanitizers, which calls for more environmentally friendly alternatives. Therefore, novel means for biofilms' control are constantly sought.

In the last decades, interest in ozone has expanded in food field, due to the growing consumers' demand for "greener" food additives, the FDA's approval of ozone directly added in foods and the increasing consciousness that ozonation represents an environmentally friendly technology. Use of ozone in food processing has been legally approved in North America, Australia, New Zealand, Japan, and several European countries (Tiwari and Rice, 2012). Ozonation is becoming widely accepted in the food context as an eco-friendly technology worldwide (O'Donnell et al., 2012). Ozone is an effective antimicrobial due to its oxidizing capacity that inactivates microorganisms by the progressive oxidation of cell components. The high instability and reactivity of ozone determine its antimicrobial properties because it rapidly degrades back to molecular oxygen without leaving toxic by-products, with the released free oxygen atom which causes oxidation (Güzel-Seydim et al., 2004). Ozonation has been successfully used in the food field to control bacterial counts in fruit and vegetable (Ölmez and Akbas, 2009), dairy (Segat et al., 2014; Marino et al., 2015), meat and seafood products (Gelman et al., 2005). It has been shown that ozone can be used to modify the chemical and physical properties of various macromolecules (Sankaran et al., 2008; An and King, 2009; Segat et al., 2015). The wide application of ozone in food field is only limited by health and safety aspects since it is a toxic compound that causes headaches, dry throat, and irritation to the respiratory system and even irreversible lethal effects at high concentrations can occur (Cullen and Norton, 2012). Therefore, efficacious systems for the detection and catalytic or thermal inactivation of ozone are required for the safety of workers in food-processing plants (Kim et al., 1999).

Ozone is commonly generated by photochemical method or corona discharge method. Another method is based on electrolysis, which allows the ozone to be dissolved in situ in the process water as soon as it is formed with the minimum amount of equipment (Chen et al., 2016). To the best of our knowledge, no bibliographic data are available on the use of ozone generated by electrolysis as an antimicrobial strategy.

Currently, the experimental data concerning the antimicrobial activity of ozone with respect to microbial biofilms in the food context are still quite limited, so the potential of the use of ozone in water and gaseous form in the control of cross-contamination is not completely clear. Moreover, the few published works have been carried out on biofilms formed by single strains coming from reference collections (Dosti et al., 2005; Di Ciccio et al., 2014; Saha et al., 2014). However, it is known that wild strains may be more resistant to antimicrobials than reference strains (Otero et al., 2014), so that recently the study protocols of the behavior of microorganisms in the food context underline the need to use wild strains too, isolated from the same or a similar food matrix. In fact, to account for differences in growth and survival among different strains of the same species, tests should be carried out with a cocktail of at least three strains, a reference strain and two wild strains (Jofré et al., 2009; ÁlvarezOrdóñez et al., 2015). The aim of this study was to investigate the disinfection efficacy of aqueous and gaseous ozone on attached cells and biofilms against foodborne bacterial strains belonging to the species Pseudomonas fluorescens, S. aureus, and L. monocytogenes. 


\section{MATERIALS AND METHODS}

\section{Microorganisms and Culture Conditions}

To account for variation in growth and survival, three strains for each species were used as follows: $P$. fluorescens: (i) CECT $378^{\mathrm{T}}$; (ii) L22, dairy isolate; and (iii) Ve096, vegetable processing plant isolate; S. aureus: (i) DSM $20231^{\mathrm{T}}$; (ii) DIAL301, processed meat isolate; and (iii) La018, dairy plant isolate; and L. monocytogenes: (i) DSM $20600^{\mathrm{T}}$; (ii) Lm5, dairy plant isolate; and (iii) Lm29, fish processing plant isolate. The species assignment was assessed by 16 S rRNA gene amplification (Martino et al., 2013). Stock cultures of each strain were stored at $-80^{\circ} \mathrm{C}$ in Brain Heart Infusion (BHI; Oxoid, Milan, Italy) supplemented with $30 \%$ (v:v) glycerol. Whenever required, stock cultures were subcultured overnight twice in $\mathrm{BHI}$ at $30^{\circ} \mathrm{C}$ (P. fluorescens) or $37^{\circ} \mathrm{C}$ (S. aureus and L. monocytogenes). Before each test, a separate cocktail of the overnight cultures (about $10^{9} \mathrm{CFU} / \mathrm{mL}$ ) of each species was prepared by mixing equal portions $(5 \mathrm{~mL})$ of each strain.

\section{Biofilm Formation and Evaluation of Biofilm Viability}

Multi-strain mono-species biofilms were grown on cylindrical stainless steel AISI 304 coupons (1.27-cm diameter, $0.3-\mathrm{cm}$ depth; area $3.73 \mathrm{~cm}^{2}$ ) subjected to sonication at $40 \mathrm{kHz}$ for $10 \mathrm{~min}$ (UltraSonic Bath LBS2, Falc Instruments, Treviglio, Italy) before each trial. To grow biofilms, $1 \mathrm{~mL}$ of each cocktail culture (prepared as previously reported) was used to inoculate $500 \mathrm{~mL}$ of Luria Bertani broth (LB; Oxoid, Milan, Italy) into the reactor vessel of CDC Biofilm Reactor (CBR; BioSurface Technologies, Bozeman, MT, United States), obtaining an initial count of about $5 \times 10^{6} \mathrm{CFU} / \mathrm{mL}$. The CBR was operated under batch phase and moderate agitation $\left(125 \mathrm{rpm}\right.$ ) during $48 \mathrm{~h}$ at $30^{\circ} \mathrm{C}$ (for P. fluorescens) or at $37^{\circ} \mathrm{C}$ (for S. aureus and L. monocytogenes) in a thermostatic chamber. After $5 \mathrm{~min}, 2 \mathrm{~h}, 4 \mathrm{~h}, 8 \mathrm{~h}, 24 \mathrm{~h}$, and $48 \mathrm{~h}$, the coupons were aseptically removed from the CBR and washed twice with $10 \mathrm{~mL}$ of sterile saline $(0.9 \% \mathrm{NaCl})$ to remove loosely adherent cells. To detach biofilm cells, each coupon was then placed in a $50-\mathrm{mL}$ sterile tube containing $3 \mathrm{~mL}$ of Maximum Recovery Diluent (MRD; Oxoid, Milan, Italy) with eight sterile glass beads (5.5 $\mathrm{mm}$ diameter) and agitated on a non-orbital shaker (Velp Scientifica, Monza, Italy) for 2 min at room temperature. The microbial suspension was serially diluted for viable counts by the spread plate technique on BHI agar plates, i.e., $0.1 \mathrm{~mL}$ of each suspension (or its decimal dilution) was put on duplicate plates. After incubation at $30^{\circ} \mathrm{C}$ or $37^{\circ} \mathrm{C}$ for $24-48 \mathrm{~h}$ and colony counting, data were expressed in $\log$ $\mathrm{CFU} / \mathrm{cm}^{2}$ (threshold CFU value $8.3 \mathrm{CFU} / \mathrm{cm}^{2}$ ).

\section{Treatments With Aqueous Ozone}

The aqueous ozone was used to treat 2-h (called from here on "attached cells") and 48-h biofilms (called from here on "biofilms"). Aqueous ozone was generated directly in tap water using an electrolytic cell (Adept -75; Electrolytic Ozone Inc., Boston, MT). Tap water was conveyed through a peristaltic pump at a rate of $1 \mathrm{~L} / \mathrm{min}$ to the electrolytic cell, which generated ozone at a concentration of about $0.5 \mathrm{mg} / \mathrm{L}$. To measure the ozone level dissolved in water a colorimetric method was used (HI 38054; Hanna Instruments, Villafranca Padovana, PD, Italy).

The aqueous ozone was used in two different ways:

(i) static, i.e., coupons carrying attached cells or biofilms were washed twice with $10 \mathrm{~mL}$ of $0.9 \% \mathrm{NaCl}(\mathrm{w} / \mathrm{v})$ and placed individually in $50 \mathrm{~mL}$ Falcon tubes, which were immediately filled with ozonated water. The tubes were closed and the coupons left for $20 \mathrm{~s}, 40 \mathrm{~s}, 1 \mathrm{~min}, 3 \mathrm{~min}$, $5 \mathrm{~min}, 10 \mathrm{~min}$, and $20 \mathrm{~min}$.

(ii) dynamic, i.e., coupons were maintained under a flow of ozonated water for $20 \mathrm{~s}, 40 \mathrm{~s}, 1 \mathrm{~min}, 3 \mathrm{~min}, 5 \mathrm{~min}, 10 \mathrm{~min}$, and $20 \mathrm{~min}$.

For each treatment, "untreated controls" were coupons aseptically removed from CDC-biofilm reactor after 2- or 48-h, and immediately analyzed for viable counts. In a preliminary step, coupons in two biological replicates and two technical repetitions were submitted to a dipping in tap water in $50 \mathrm{~mL}$ Falcon tubes for $20 \mathrm{~min}$ (to simulate static treatment), and a maintenance under a continuous flow ( $1 \mathrm{~L} / \mathrm{min}$ ) of tap water for $20 \mathrm{~min}$ (dynamic treatment). Viable counts were then evaluated and means submitted to $T$-test against means of coupons just after removing from CDC-Biofilm Reactor. In all cases means resulted similar $(p>0.05)$.

The treatments were carried out at room temperature (RT; $20^{\circ} \mathrm{C}$ ). After each treatment, the cells were detached from coupons and submitted to viable count evaluation as previously reported.

\section{Evaluation of Ozone Decay in Water}

The decay of ozone concentration in water in the static conditions was measured using a colorimetric method (as previously described). Fifty milliliter of ozonated water were placed in $50 \mathrm{~mL}$ Falcon tubes and left at RT. After 0, 1, 5, 10, and $20 \mathrm{~min}$, the ozone concentration was measured. At least two tubes for each time were tested.

\section{Treatments With Gaseous Ozone}

The gaseous ozone was used to treat biofilms. Coupons were washed as previously reported and placed individually in $60 \mathrm{~mm}$ Petri dishes and placed inside a treatment chamber connected to an ozone generator (AIRNow OG-36AN2K; O3 Technology, Brescia, Italy) and equipped with an ozone analyzer (BMT 964; Mes-stechnik GMBH, Villach, Austria). Treatments were carried out at concentrations of $0.1,0.15,0.2,2,5$, and $20 \mathrm{ppm}$ for exposure times of $2,5,7,10,20,30$, and $60 \mathrm{~min}$. At the end of each treatment, coupons were evaluated for viable counts as previously described.

For each treatment, "untreated controls" were coupons aseptically removed from CDC-Biofilm Reactor after 48-h and immediately analyzed for viable counts. In a preliminary step, coupons in two biological replicates and two technical repetitions were maintained inside the treatment chamber with the ozone generator in "OFF" position for $60 \mathrm{~min}$. Viable counts were then evaluated, and means submitted to $T$-test against means of 
coupons just after removing from CDC-Biofilm Reactor. In all cases means resulted similar $(p>0.05)$.

\section{Statistical Analysis}

Each trial was carried out in at least two biological replicates, i.e., parallel measurements of biologically distinct samples (cocktail culture independently grown). For each biological replicate, viability was evaluated on two coupons (two technical repetitions). The means obtained from replicate tests were subjected to one-way analysis of variance $(p<0.05)$, preceded by the Levene test to verify the homogeneity of variance between means using the Statistics 8.0 (Statsoft software, Tulsa, OK, United States). Differences between the means were assessed using the Tukey's HSD post hoc test.

The microbial population densities $\left(\mathrm{CFU} / \mathrm{cm}^{2}\right)$ observed in the biofilm formation experiments were log-transformed and modeled with the Baranyi and Roberts model (Baranyi and Roberts, 1994). The Excel add-in DMFit ver. 3.0 (Baranyi and Tamplin, 2004) was used to calculate the estimates of kinetic parameters, i.e., initial count (expressed in $\mathrm{Log} \mathrm{CFU} / \mathrm{cm}^{2}$ ), lag time $(\mathrm{h})$, maximum growth rate $\left(\log \mathrm{CFU} / \mathrm{cm}^{2} / \mathrm{h}\right)$ and maximum cell count $\left(\log \mathrm{CFU} / \mathrm{cm}^{2}\right)$.

To model the survival of the attached cells and biofilms to ozone treatments, $\log \left(\mathrm{N} / \mathrm{N}_{0}\right)$ values were calculated, where $N=$ viable count and $N_{0}=$ initial viable count (untreated controls). Log $\left(N / N_{0}\right)$ values were shaped through the GInaFIT tool ver. 1.7 (Geeraerd et al., 2005). The goodness-of-fit was assessed based on the coefficient of determination $\left(R^{2}\right)$ and the root mean squared error (RMSE).

\section{RESULTS}

\section{Adhesion Kinetics on Stainless Steel}

Figure 1 shows the adhesion kinetics of $P$. fluorescens, $S$. aureus, and L. monocytogenes on AISI 304 stainless steel coupons during a 48 -h incubation at $30^{\circ} \mathrm{C}$ ( $P$. fluorescens) or $37^{\circ} \mathrm{C}$ (S. aureus and L. monocytogenes). The kinetics were fitted according to the model of Baranyi and Roberts, with acceptable values of goodness-of-fit (Table 1). All species showed a rapid growth with no lag time. $P$. fluorescens was the fastest species in the very early adhesion phases, reaching viability values of $5.79 \mathrm{Log} \mathrm{CFU} / \mathrm{cm}^{2}$ after $2 \mathrm{~h}$ of incubation. Instead, S. aureus and L. monocytogenes showed lower values $(p<0.05), 4.24$ and $3.88 \mathrm{Log} \mathrm{CFU} / \mathrm{cm}^{2}$, respectively. P. fluorescens biofilms had also the highest viability after $48 \mathrm{~h}\left(6.70 \mathrm{Log} \mathrm{CFU} / \mathrm{cm}^{2}\right)$. In contrast, L. monocytogenes and $S$. aureus showed significantly lower values of viability at the end of the incubation $(p<0.05)$. L. monocytogenes showed also the lowest value of maximum adhesion speed.

\section{Ozone Decay in Water}

The concentration of ozone was measured at different time points (from 0 to $20 \mathrm{~min}$ ) in closed test-tubes, mimicking the static treatments with aqueous ozone. At time 0 , the ozone concentration in water was $0.48 \pm 0.06 \mathrm{mg} / \mathrm{L}$, and the concentration progressively decreased reaching mean values of
$0.15 \mathrm{mg} / \mathrm{L}$ after $20 \mathrm{~min}$. The ozone decay followed a first-order kinetic, with a very high $R^{2}$ value (Figure 2 ).

\section{Treatments With Ozonated Water}

The effect of ozonated water applied as static and dynamic treatment was evaluated on attached cells and biofilms. The mean viable counts on stainless steel coupons at the beginning of the treatment (untreated controls) were as follows: (i) for attached cells, $5.79 \pm 0.18,4.24 \pm 0.12$, and $3.88 \pm 0.28 \mathrm{Log} \mathrm{CFU} / \mathrm{cm}^{2}$ for $P$. fluorescens, S. aureus, and L. monocytogenes, respectively; and (ii) for biofilms, $6.96 \pm 0.25,5.47 \pm 0.27$, and $5.33 \pm 0.18 \mathrm{Log}$ $\mathrm{CFU} / \mathrm{cm}^{2}$. The counts decreased by increasing the treatment time (see Supplementary Tables). The GInaFiT tool was used to estimate the resistance parameters and to identify which model was the best fit for survival curves (Geeraerd et al., 2005). According to our experimental data, the log-linear model with a tail (Geeraerd et al., 2000) was the most appropriate amongst the GInaFiTt list to describe the inactivation kinetics of attached cells treated with ozonated water, as can be seen in Figure 3. In fact, the application of this model returned $R^{2}$ values significantly higher compared to other models (data not reported). Moreover, relatively low RMSE values were obtained for all trials (Table 2). The fitting with a log-linear model with tail allowed to estimate the specific inactivation rate $k_{\max }(1 / \mathrm{min})$, and the $\log \mathrm{N}_{\text {res }}$, which is the residual population density $\left(\log \mathrm{CFU} / \mathrm{cm}^{2}\right)$ at the end of the treatment. Regardless of the microbial species, the inactivation rate of aqueous ozone applied in dynamic conditions was significantly higher than static ones $(p<0.05)$. Moreover, dynamic treatments caused the lowest survival rates on $S$. aureus and $P$. fluorescens attached cells, since the Log $N_{\text {res }}$ were lower in this condition compared to static one. L. monocytogenes attached cells were instead similarly affected in both conditions.

Unlike attached cells, the most appropriate model to describe the inactivation kinetics of biofilms was the Weibull model (Figure 4), which showed a strong fit, as indicated by the high coefficients of determination $\left(R^{2}>0.91\right)$ and low RMSE observed for all microbial species (Table 3 ). The fitting with the Weibull model allowed estimating $D_{\beta}$ value, which is the decimal reduction time, i.e., the time for the first decimal reduction of the biofilm viable counts, and $B$ parameter, which is a shape parameter. Many survival curves exhibit concavity, either downward or upward, and the $ß$ parameter is used to describe this concavity. The $\beta$ parameters were all less than 1 , which indicates the presence of a tail in the curve. As for attached cells, the dynamic treatments of biofilms with aqueous ozone were the most effective, since the $D_{\beta}$ values were lower than static ones, indicating that fewer minutes were required to achieve the $90 \%$ inactivation of viable counts. Regardless of microbial species, the antimicrobial effect was stronger in dynamic conditions, since the residual microbial populations after $20 \mathrm{~min}$ were lower than in static condition.

\section{Treatment of Biofilms With Gaseous Ozone}

As for biofilms treated with aqueous ozone in dynamic conditions, Weibull model gave the best fit of inactivation 


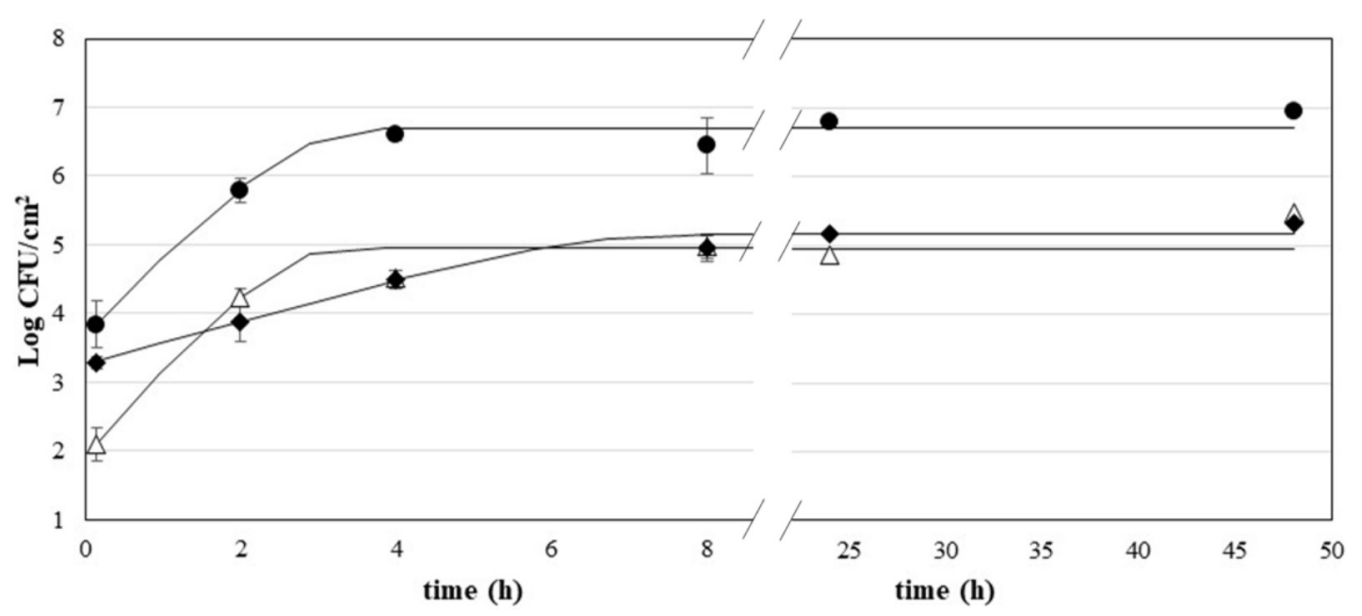

FIGURE 1 | Growth of $P$. fluorescens

), S. aureus $(\triangle)$, and L. monocytogenes (

) on stainless steel; curves are fitted using the Baranyi and Roberts model.

TABLE 1 | Kinetic parameters of $P$. fluorescens, S. aureus, and L. monocytogenes estimated by fitting Baranyi and Roberts model to growth data on stainless steel.

\begin{tabular}{|c|c|c|c|c|c|}
\hline & Initial cell count* & Maximum growth rate ${ }^{\dagger}$ & Maximum cell count ${ }^{\S}$ & $R^{2}$ & RMSE \\
\hline Staphylococcus aureus & $2.09^{C} \pm 0.40$ & $1.08^{a} \pm 0.30$ & $4.96^{b} \pm 0.20$ & 0.89 & 0.40 \\
\hline
\end{tabular}

${ }^{*} \mathrm{Log} \mathrm{CFU} / \mathrm{cm}^{2} ;{ }^{\dagger} \log \mathrm{CFU} / \mathrm{cm}^{2} / \mathrm{h} ;{ }^{\S} \mathrm{Log} \mathrm{CFU} / \mathrm{cm}^{2}$. For each column, means followed by different letters are significantly different $(p<0.05)$.

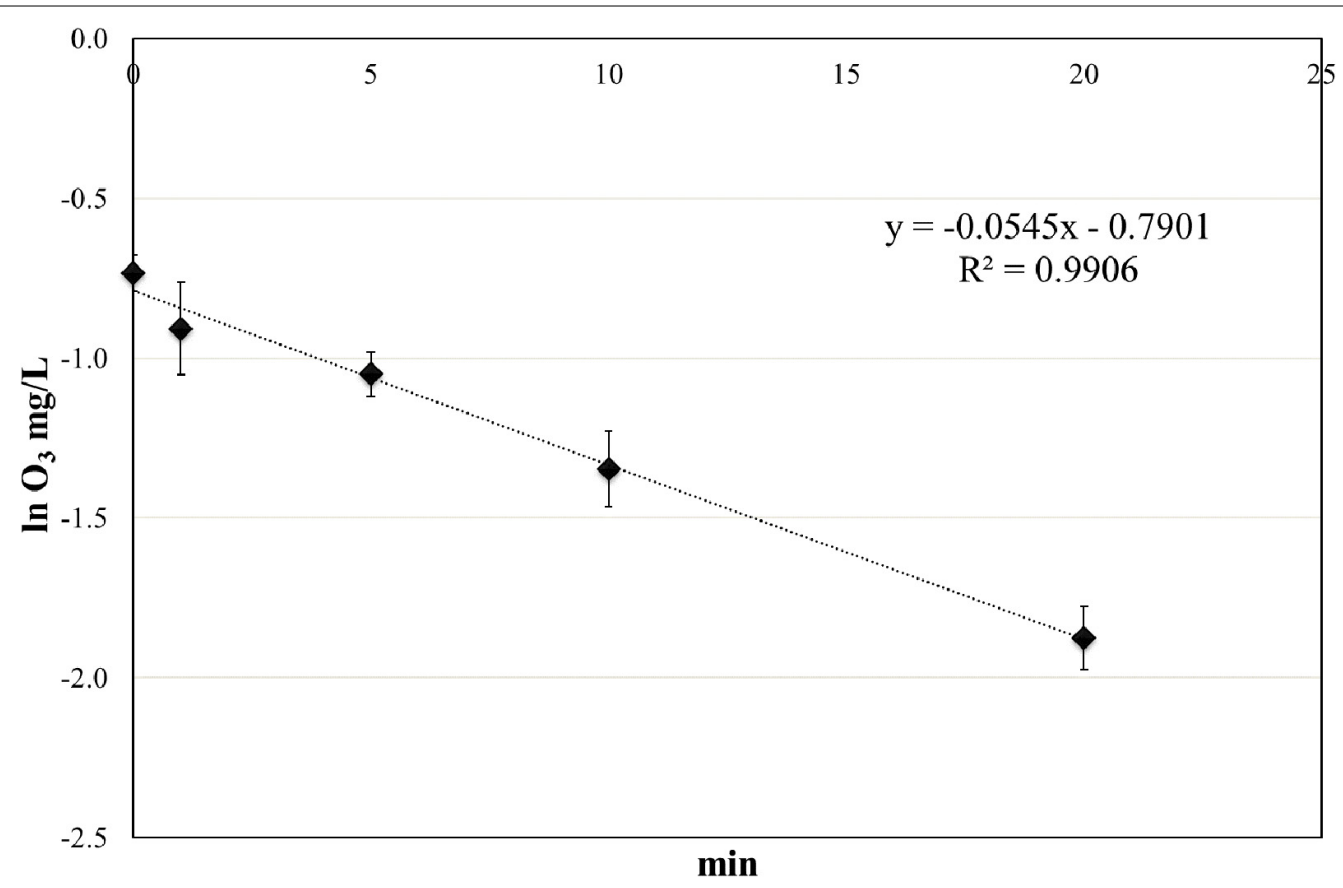

FIGURE 2 | Ozone decay in tap water at room temperature (RT).

kinetics of biofilms treated with gaseous ozone, as evidenced by high $R^{2}$ and low RMSE values (Table 4 ). The $\beta$ parameters were all lower than 1 , indicating a tail in the inactivation curve (Figure 5). As expected, regardless of the microbial species the $D_{\beta}$ values decreased by increasing the ozone concentration. L. monocytogenes showed to be the most resistant species at the lowest ozone concentration $(0.1 \mathrm{ppm})$, having $D_{\beta}=19.74 \mathrm{~min}$ compared to $D_{\beta}=12.38 \mathrm{~min}$ and $D_{\beta}=10.32$ 

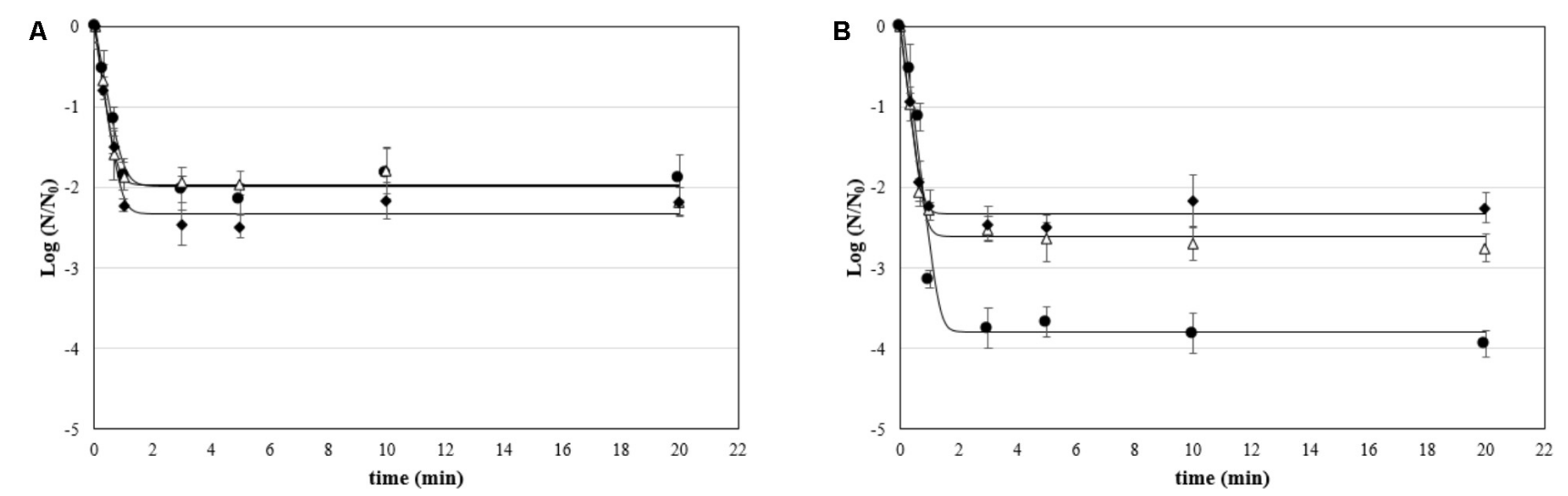

FIGURE 3 | Survival (Log N/No) of attached cells treated with aqueous ozone in (A) static and (B) dynamic condition for $P$. fluorescens $(\mathbf{\bullet})$, S. aureus ( $\triangle$ ), and L. monocytogenes $(\bullet)$; curves are fitted using the log-linear + tail model.

TABLE 2 | Kinetic parameters ( $k_{\max }$, specific inactivation constant, and Log $N_{\text {res, }}$, residual population density) and goodness-of-fit parameters of the log-linear + tail model for inactivation by aqueous ozone of attached cells of $P$. fluorescens, $S$. aureus, and L. monocytogenes.

\begin{tabular}{|c|c|c|c|c|c|}
\hline & Treatment condition & $k_{\max }{ }^{*}$ & $\log N_{\text {res }}^{\dagger}$ & $R^{2}$ & RMSE \\
\hline & Dynamic & $6.85^{a, b} \pm 0.48$ & $1.55^{\mathrm{C}} \pm 0.17$ & 0.890 & 0.192 \\
\hline & Dynamic & $7.32^{\mathrm{a}} \pm 0.17$ & $1.50^{C} \pm 0.03$ & 0.934 & 0.072 \\
\hline \multirow[t]{2}{*}{ Listeria monocytogenes } & Static & $6.69^{b} \pm 0.37$ & $1.46^{c} \pm 0.08$ & 0.981 & 0.167 \\
\hline & Dynamic & $7.48^{\mathrm{a}} \pm 0.29$ & $1.63^{c} \pm 0.06$ & 0.961 & 0.157 \\
\hline
\end{tabular}

*1/min; ${ }^{\dagger} \mathrm{CFU} / \mathrm{cm}^{2}$. For each column, means followed by different letters are significantly different $(p<0.05)$.
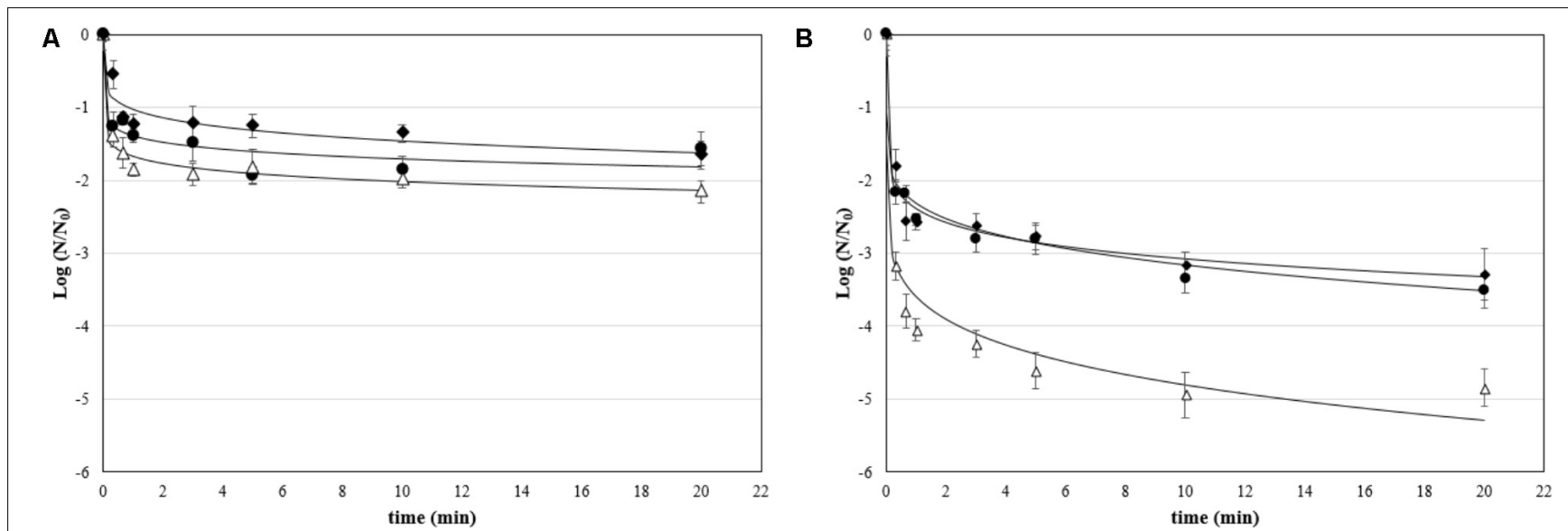

FIGURE 4 | Survival (Log N/No) of biofilms treated with aqueous ozone in (A) static and (B) dynamic condition for P. fluorescens $(\mathbf{\bullet}), S$. aureus $(\triangle)$, and L. monocytogenes $(\bullet$; curves are fitted using the Weibull model.

for $P$. fluorescens and $S$. aureus, respectively. Interestingly, starting from $2 \mathrm{ppm}$ the viability of L. monocytogenes was undetectable (i.e., $<8.3 \mathrm{CFU} / \mathrm{cm}^{2}$ ) even at the 2 -min treatments. As for $P$. fluorescens, it was the most resistant species at the highest ozone concentrations, since a residual viability was observed after the treatment at $20 \mathrm{ppm}$ up to $60 \mathrm{~min}$. S. aureus, instead, survived the treatment at $20 \mathrm{ppm}$ only for $10 \mathrm{~min}$.

\section{DISCUSSION}

The use of ozone and ozonation treatments has proven to be effective as an antimicrobial approach in different contexts, including medical, agricultural, marine, and food (Srikanth et al., 2013; Guo and Wang, 2017). As for the food field, ozone has shown to be a valuable tool for decontaminating different categories of products including dairy, fruit and vegetables, 
TABLE 3 | Kinetic parameters ( $D_{\beta}$, decimal reduction time; $\beta$, shape parameter) of Weibull model for inactivation by aqueous ozone of biofilms of $P$. fluorescens, S. aureus, and L. monocytogenes.

\begin{tabular}{|c|c|c|c|c|c|}
\hline & Treatment condition & $D_{\beta}{ }^{*}$ & $\beta$ & $R^{2}$ & RMSE \\
\hline \multirow[t]{2}{*}{ Pseudomonas fluorescens } & Static & $0.23^{b} \pm 0.15$ & $0.09^{b} \pm 0.06$ & 0.917 & 0.271 \\
\hline & Dynamic & $0.02^{c} \pm 0.00$ & $0.17^{\mathrm{a}} \pm 0.06$ & 0.952 & 0.314 \\
\hline \multirow[t]{2}{*}{ Staphylococcus aureus } & Static & $0.02^{c} \pm 0.00$ & $0.08^{b} \pm 0.02$ & 0.971 & 0.121 \\
\hline & Dynamic & $0.01^{\mathrm{c}} \pm 0.00$ & $0.11^{a, b} \pm 0.03$ & 0.984 & 0.290 \\
\hline \multirow[t]{2}{*}{ Listeria monocytogenes } & Static & $1.16^{\mathrm{a}} \pm 0.16$ & $0.15^{\mathrm{a}} \pm 0.06$ & 0.930 & 0.213 \\
\hline & Dynamic & $0.05^{\mathrm{C}} \pm 0.00$ & $0.20^{a} \pm 0.08$ & 0.919 & 0.185 \\
\hline
\end{tabular}

*min. For each column, means followed by different letters are significantly different ( $p<0.05)$.

TABLE 4 | Kinetic parameters ( $D_{\beta}$, decimal reduction time; $\beta$, shape parameter) of Weibull model for inactivation by different concentrations of gaseous ozone of biofilms of $P$. fluorescens, S. aureus, and L. monocytogenes.

\begin{tabular}{|c|c|c|c|c|c|}
\hline & Ozone ppm & $D_{\beta}{ }^{*}$ & $\beta$ & $R^{2}$ & RMSE \\
\hline \multirow[t]{6}{*}{ Pseudomonas fluorescens } & 0.1 & $12.38^{b} \pm 2.04$ & $0.29^{a, b} \pm 0.04$ & 0.94 & 0.11 \\
\hline & 0.15 & $7.75^{d} \pm 1.55$ & $0.13^{b} \pm 0.05$ & 0.94 & 0.15 \\
\hline & 0.2 & $1.39^{f} \pm 0.19$ & $0.18^{b} \pm 0.03$ & 0.97 & 0.12 \\
\hline & 2 & $0.63^{9} \pm 0.02$ & $0.16^{b} \pm 0.19$ & 0.83 & 0.43 \\
\hline & 5 & $0.50^{9} \pm 0.01$ & $0.33^{a} \pm 0.11$ & 0.97 & 0.18 \\
\hline & 20 & $0.33^{9} \pm 0.00$ & $0.33^{a} \pm 0.12$ & 0.95 & 0.24 \\
\hline \multirow[t]{6}{*}{ Staphylococcus aureus } & 0.1 & $10.32^{\mathrm{c}} \pm 1.17$ & $0.27^{a, b} \pm 0.02$ & 0.93 & 0.15 \\
\hline & 0.15 & $3.18^{\mathrm{e}} \pm 0.89$ & $0.19^{b} \pm 0.09$ & 0.92 & 0.12 \\
\hline & 0.2 & $1.10^{f} \pm 0.14$ & $0.22^{b} \pm 0.01$ & 0.90 & 0.09 \\
\hline & 2 & $0.30^{9} \pm 0.24$ & $0.24^{b} \pm 0.12$ & 0.94 & 0.21 \\
\hline & 5 & $0.18^{\mathrm{h}} \pm 0.19$ & $0.35^{\mathrm{a}} \pm 0.22$ & 0.90 & 0.23 \\
\hline & 20 & $0.15^{\mathrm{h}} \pm 0.017$ & $0.37^{a} \pm 0.14$ & 0.89 & 0.28 \\
\hline \multirow[t]{3}{*}{ Listeria monocytogenes } & 0.1 & $19.74^{a} \pm 2.98$ & $0.26^{a, b} \pm 0.10$ & 0.90 & 0.17 \\
\hline & 0.15 & $9.87^{d} \pm 2.45$ & $0.38^{a} \pm 0.06$ & 0.93 & 0.15 \\
\hline & 0.2 & $8.70^{d} \pm 1.18$ & $0.37^{a} \pm 0.07$ & 0.95 & 0.13 \\
\hline
\end{tabular}

*min. For each column, means followed by different letters are significantly different $(p<0.05)$.

meat and fish, as well as for modifying the textural properties of foods and to inactivate enzymatic activities (Segat et al., 2016; Pinto et al., 2017). Although the role of microbial biofilms as contaminating agents in the food chain is of particular importance, studies on the effectiveness of ozone as an antimicrobial agent against biofilms are currently quite scarce. It is known that the capacity of microorganisms to attach to surfaces and form biofilms is influenced by several factors, which include the chemical-physical characteristics of the material, the incubation conditions, and the microbial strain (Carpentier and Cerf, 1993). All these parameters can also influence the tolerance of microbial cells to the anti-biofilm treatments that are carried out. For this reason, in a preliminary step of the study, the adhesion kinetics of the three microbial species to AISI 304 stainless steel, a widely used material in the food industry for its ease of cleaning and its ability to resist corrosion, have been characterized (Jullien et al., 2003). To account for diversity in growth and survival among different strains of the same species, in this study each trial was carried out using three different strains (one reference and two wild strains) for each microbial species. All three microbial species have shown to adhere very rapidly to stainless steel, probably due to the presence of cell appendages such as pili or fimbriae and flagella, as well as the formation of EPS (Norwood and Gilmour, 1999; Giltner et al., 2006). After 2 h, P. fluorescens adhered with a viability of $5.79 \mathrm{Log} \mathrm{CFU} / \mathrm{cm}^{2}$ and reached its maximum value after just $4 \mathrm{~h}$. The presence of Pseudomonas spp. in the food industry is quite risky because they can produce hydrolytic enzymes, pigments, and slimes, which can cause food spoilage, mostly in refrigerated foods (Rajmohan et al., 2002). They can produce exopolymers and attach rapidly to surfaces in the food plants, where they are frequently found. Thus, they can act as reservoirs for the repeated contamination of foods (Lemos et al., 2015). Analogous considerations can be made as for $S$. aureus, which showed to be very fast in adhesion to stainless steel. In fact, the maximum growth rate was similar to that of $P$. fluorescens. However, the maximum cell count after $48 \mathrm{~h}$ for $S$. aureus was about 2-Log lower than that of $P$. fluorescens. This result is in agreement with previous studies, which showed that $S$. aureus biofilms are usually less dense than P. fluorescens ones (Rossoni and Gaylarde, 2000; Nielsen et al., 2018). Nevertheless, S. aureus biofilms could cause cross-contamination via surfaces in the food field. It has to be highlighted that $S$. aureus can cause is food poisoning by producing toxins in food and is a main player in major food poisoning outbreaks worldwide (Bartolomeoli et al., 2009; 

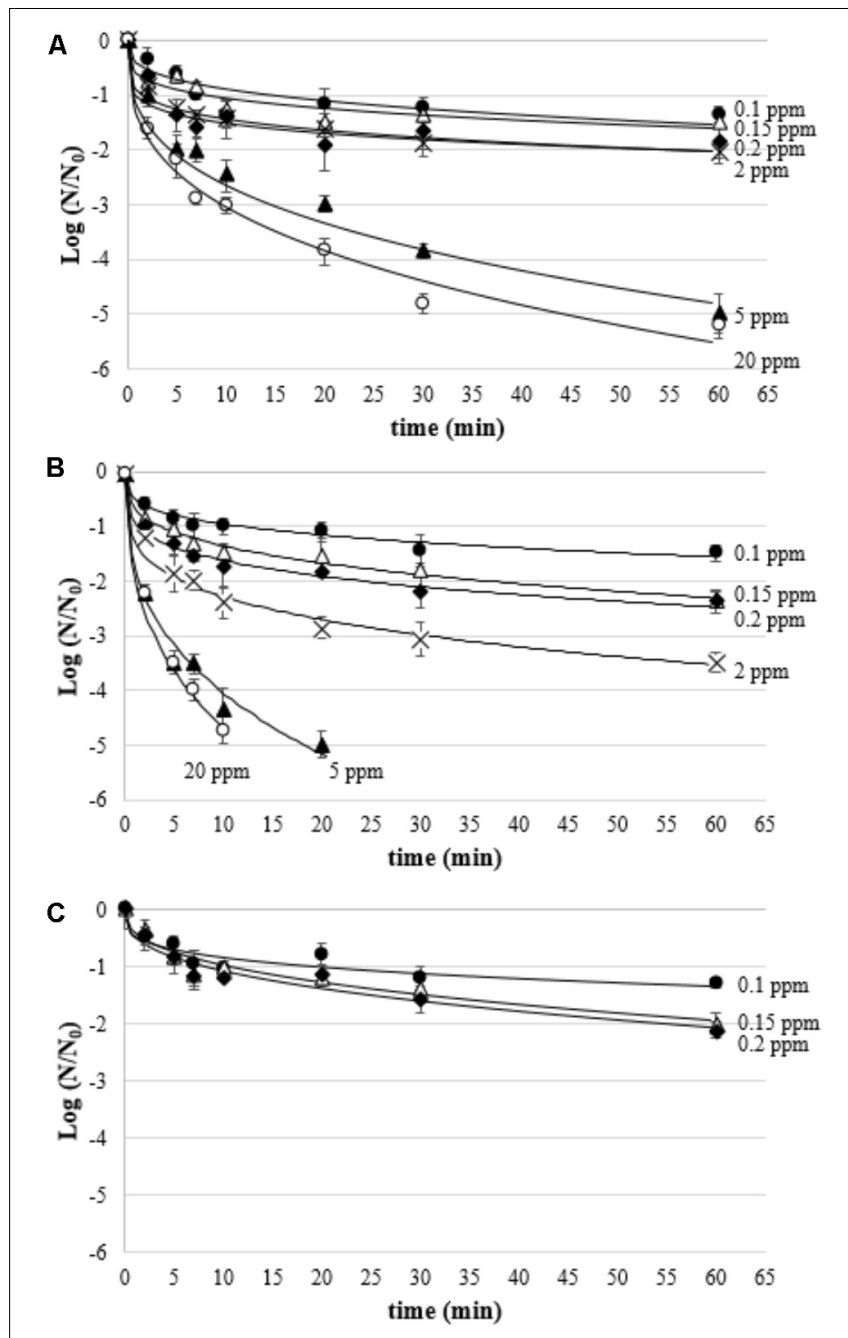

FIGURE 5 | Survival (Log $N / N_{0}$ ) of $P$. fluorescens (A), S. aureus (B), and L. monocytogenes (C) biofilms treated with gaseous ozone at $0.1 \mathrm{ppm}(\mathbf{\bullet})$, $0.15 \mathrm{ppm}(\Delta), 0.2 \mathrm{ppm}(\boldsymbol{\vee}), 2 \mathrm{ppm}(\times), 5 \mathrm{ppm}(\mathbf{\Lambda})$, and $20 \mathrm{ppm}(O)$; curves are fitted using the Weibull model.

Ercoli et al., 2017). In the United States, S. aureus accounts for more than 240,000 foodborne illnesses per year (Scallan et al., 2011). L. monocytogenes showed a slower adhesion kinetic and reached the maximum adhesion after $8 \mathrm{~h}$. Although reaching final count values lower than $P$. fluorescens, these remained quite considerable (5.16 Log $\left.\mathrm{CFU} / \mathrm{cm}^{2}\right)$. L. monocytogenes is considered as one of the key foodborne pathogens of concern, which is responsible for listeriosis in humans, primarily the elderly, pregnant women, and immunocompromised individuals (Ferreira et al., 2014). In the period 2008-2016, there has been an increasing trend of confirmed listeriosis cases, and EFSA reported 2,536 confirmed human cases of listeriosis in 2016. The pathogen was most frequently detected in fish and fishery products, pork meat products, and in soft and semi-soft cheeses made from raw or low-heat-treated milk (EFSA, 2017). This pathogen can successfully colonize food-contact surfaces, and therefore resist for long time in food plants.
The treatments were carried out on attached cells (2-h) and true biofilms (48-h). As for attached cells, several studies indicate that irreversible attachment to surfaces takes from $20 \mathrm{~min}$ to a maximum of $4 \mathrm{~h}$ (Gilbert et al., 1991; Lundén et al., 2000; Vatanyoopaisarn et al., 2000). As for "biofilm" referring to 48-h cells, similarly, the term "biofilm" is used for cells grown on different materials (including stainless steel) just after $24 \mathrm{~h}$ (Di Bonaventura et al., 2008; Williams et al., 2011; Corcoran et al., 2014). The treatments with ozonated water have been applied in two different ways, static and dynamic, that could simulate different uses in the sanitation protocols in the food plants. In the case of treatments under static conditions, these might mimic the dipping of small equipment or disassembled parts of these during brief pauses of the processing operations. Under these conditions, the ozone concentration would be maximum at the beginning of the dipping and would decrease progressively over time due to the decay of the ozone itself. In the case of treatments under dynamic conditions, instead, the surfaces might be treated with a continuous flow of water in which the concentration of ozone remains almost constant since it comes from an ozone generator that operates continuously.

In this study, the inactivation data are reported as values of $\log \left(N / N_{0}\right)$, that consider both the initial viable counts $\left(N_{0}\right.$, untreated control) and the viable counts after the treatment $(N)$. Such way of expressing microbial inactivation is common in the food context (Chang and Craik, 2012). No positive control was prepared, as usual in similar studies (Baumann et al., 2009; Nicholas et al., 2013; de Candia et al., 2015). In fact, in the food field a "gold standard treatment" for biofilm studies doesn't exist, but a list of measures differently active in terms of active substance, time of treatment, and temperature exists. By using the GInaFiT tool, it was evidenced that the kinetics of attached cells' inactivation by aqueous ozone were well described by the log-linear + tail model, i.e., a first part in which all cells in the population possess the same resistance, followed by a tail related to the existence of a sub-resistant population. It means that the main inactivation occurred in the first minutes of treatment. Afterward, with increasing treatment time, microbial viability remained constant, not undergoing any significant inactivation. The application of aqueous ozone in the two different modalities had different antimicrobial effects in this study. In particular, the rate of inactivation of the attached cells was higher in the dynamic conditions than static ones regardless of the microbial species. The lower inactivation rates of biofilms in static conditions could be attributed to the fact that the ozone concentration in water progressively decreased over time due to decay. In the treatment conditions tested, in fact, the half-time of ozone was about $10 \mathrm{~min}$. Despite this, at the end of treatment under static conditions (20 min), the log reduction of the microbial load was similar for the three species tested and in the range $2.24-2.43 \mathrm{Log} \mathrm{CFU} / \mathrm{cm}^{2}$, as inferred by the viabilities of attached cells and the Log $N_{\text {res }}$ estimated by the model. In the treatments carried out under dynamic conditions, instead, the microorganisms proved to be differently sensitive to treatment. In particular, L. monocytogenes was the most resistant species, followed by $S$. aureus and $P$. fluorescens. In the literature, no correlation between the antimicrobial efficacy of 
ozone and the belonging of microorganisms to the Gram-positive or Gram-negative group has been found. In this study, the higher resistance of L. monocytogenes and S. aureus species compared to $P$. fluorescens might be related to cellular defense systems against oxidative stress, which are present in both species (Ferreira et al., 2001; Clauditz et al., 2006). As for P. fluorescens, the presence of the outer membrane, which can be a cellular shield against other antimicrobial systems (Marino et al., 2001), has not given any defense. Probably, indeed, it has been the first target of the ozone oxidative activity, causing a very high overall loss of viability.

Biofilms treated with ozonated water displayed inactivation kinetics described by the Weibull model with a concave shape. The presence of a concave curve, and not log-linear as in the case of attached cells, could be linked to the fact that the biofilms, being more mature, are made up of a more heterogeneous cell population in terms of age and therefore of physiology (Wimpenny et al., 2000). The existence of a tail clearly indicates that, as in the case of attached cells, a portion of the microbial population is resistant to treatment, due to inherent or acquired resistances during ozonation treatment (Valdramidis et al., 2012). This behavior related to ozonation treatments was also observed by other authors, although not for sessile microorganisms, i.e., in the form of biofilms (Brodowska et al., 2017). The values of the $D_{\beta}$ parameter estimated by the Weibull model in this study indicate that the dynamic treatment was very effective, as it was able to inactivate $90 \%$ of the microbial population in the biofilms in a few seconds. Such a treatment applied during downtime during the day immediately after the removal of gross soil, or at the end of the day immediately before the disinfection operation, could contribute to the reduction of the risk of cross-contamination by biofilm.

It is well known that the resistance of biofilms to antimicrobials increases with the age of the biofilm. In fact, adhesion and progressive colonization of surfaces lead to important changes in gene expression and microbial proteomics, which result in an increase in the ability of microbial cells to overcome stress (Fatemi and Frank, 1999; Tremoulet et al., 2002). The data obtained in this study instead show that, when the concentration of ozone in water remains almost constant (under dynamic treatment conditions), biofilms of $S$. aureus and L. monocytogenes are more sensitive than attached cells. The reasons for this phenomenon are not clear, even if the mechanisms of resistance seem to be linked to multiple factors and may vary from organism to organism (Patel, 2005). In any case, regardless of the microbial species, the use of aqueous ozone in dynamic condition was able to cause a microbial inactivation of at least 3-Log of biofilm viability after less than $2 \mathrm{~min}$ for $S$. aureus and about $8 \mathrm{~min}$ for $P$. fluorescens and L. monocytogenes. This level of inactivation is considered the minimum inactivation target required for antimicrobials used on biofilms (Mosteller and Bishop, 1993; Rodrigues et al., 2011). These results clearly show that ozonated water can be an effective tool in the control of microbial biofilms in the food industry. It should also be emphasized that this technology is environmental-friendly as the system can be powered simply by tap water. Moreover, the only products generated by the electrolytic cell are ozone, oxygen, and water, so the system does not generate undesired residues (Honda et al., 2013). The use of ozonated water in the food industry is generally obtained through an enrichment of the water with ozone produced by photochemical effect or by the so-called "corona effect" (Tapp and Rice, 2012). Regardless of the ozone generation mode, this must then be dissolved in water through a Venturi system or through appropriate bubble diffusers. A complete system of ozonation of this type consists of several types of equipment, among which oxygen tanks, ozone generator, pumps, valves, and injectors, with consequent high costs both in economic terms and risks for the operators related to the use of high pressures. In the light of these considerations, the possibility of producing ozonated water in situ from simple tap water using an electrolytic cell seems to be quite intriguing. Although this requires an extra investment for a minor additional amount of infrastructure in the form of an electrolytic ozone generator, the transportation of potentially dangerous chemicals or the high running costs of an ozone sterilization unit are avoided.

As for aqueous ozone applied in dynamic conditions, the kinetics of inactivation of biofilms through the use of ozone in gaseous form showed a trend described by the Weibull model with tail, indicating that this type of behavior generally characterizes microbial inactivation caused by oxidative processes following ozonation. Gaseous ozone showed to be a less effective antimicrobial than aqueous ozone. In fact, the $D_{\beta}$ values, which measure the time necessary to inactivate $90 \%$ of the biofilm viability, were always higher in the case of gaseous ozone, regardless of concentration. The moderate effect exerted by gaseous ozone is strictly due to the mechanism of action of the ozone, which requires the presence of water (Martinelli et al., 2017). Theoretically, increasing the relative humidity could increase the efficiency of gaseous ozone, thus shortening exposure times (Pascual et al., 2007). Despite this, in some conditions, the treatment with gaseous ozone was able to achieve the minimum required efficiency, i.e., $3 \mathrm{Log} \mathrm{CFU} / \mathrm{cm}^{2}$. In particular, the application of gaseous ozone at a concentration of 5 ppm inactivated 3 Log of microbial biofilms of $P$. fluorescens and $S$. aureus in approximatively 17 and $6 \mathrm{~min}$, respectively. L. monocytogenes biofilms showed an unusual behavior, since at the lowest ozone concentrations (up to $0.2 \mathrm{ppm}$ ), the viability loss after $60 \mathrm{~min}$ was similar to $S$. aureus and $P$. fluorescens, whereas starting from $2 \mathrm{ppm}$ it couldn't survive $\left(<10 \mathrm{CFU} / \mathrm{cm}^{2}\right)$ even after the shortest treatments. Such inactivation levels are particularly interesting as they could be applied to reduce the risk of biofilm in confined environments such as the ripening rooms or warehouses, where biofilms of potentially pathogenic or spoilage microorganisms may occur (Muhterem-Uyar et al., 2015). As for L. monocytogenes, it may be present in the biofilm environment of the food industry areas not subject to daily sanitation (Carpentier and Cerf, 1993). The use of ozone in the ripening rooms, carried out in the absence of a product to avoid potential oxidative damage to the lipid component, appears particularly interesting, as these are high humidity environments, which can increase the efficiency of the treatment. Furthermore, this treatment could be carried out during the night in the absence of the personnel in charge, in order to reduce the risks of toxicity related to prolonged exposure to ozone. Such a time 
interval can be considered sufficient to obtain a satisfactory reduction of the microbial load and at the same time a natural decay of the gaseous ozone, which spontaneously degrades to oxygen (Batakliev et al., 2014). It is also possible to accelerate the ozone decay through specific catalysts or UV lamps in order to further reduce the risks for the operators (Ku et al., 1996; Park et al., 2004).

\section{CONCLUSION}

The results of this study clearly show that the use of ozone in both aqueous and gaseous form, can have great exploitability in the food industry to reduce the risk related to the presence of microbial biofilms. The use of aqueous ozone can find application in daily practices of equipment sanitizing, both during plant shutdown and at the end of the day. Ozonated water, especially if used in a dynamic condition, can cause a microbial inactivation of at least $3 \mathrm{Log}$, which is considered a minimum requirement for the antimicrobial substances on biofilms. The fast decay rate of the ozone in these conditions greatly reduces the risk for the operators. Furthermore, the production of ozonized water through an electrolytic cell requires a simple generation system but does not imply further costs of adding ozone to water, as ozone is generated in situ directly in tap water. As for gaseous ozone, it is active at higher concentrations, however it could be applied in confined environments (e.g., ripening rooms) overnight, in the absence of the operators to minimize the risk to health. The microorganisms studied in this study are possible causes of spoilage or foodborne diseases, then

\section{REFERENCES}

Álvarez-Ordóñez, A., Leong, D., Hickey, B., Beaufort, A., and Jordan, K. (2015). The challenge of challenge testing to monitor Listeria monocytogenes growth on ready-to-eat foods in Europe by following the European Commission (2014) Technical Guidance document. Food Res. Int. 75, 233-243. doi: 10.1016/j. foodres.2015.06.004

An, H. J., and King, J. M. (2009). Using ozonation and amino acids to change pasting properties of rice starch. J. Food Sci. 74, C278-C2883. doi: 10.1111/j. 1750-3841.2009.01109.x

Baranyi, J., and Roberts, T. A. (1994). A dynamic approach to predicting bacterial growth in food. Int. J. Food Microbiol. 23, 277-294. doi: 10.1016/0168-1605(94) 90157-0

Baranyi, J., and Tamplin, M. L. (2004). ComBase: a common database on microbial responses to food environments. J. Food Prot. 67, 1967-1971. doi: 10.4315/ 0362-028X-67.9.1967

Bartolomeoli, I., Maifreni, M., Frigo, F., Urli, G., and Marino, M. (2009). Occurrence and characterization of Staphylococcus aureus isolated from raw milk for cheesemaking. Int. J. Dairy Technol. 62, 366-371. doi: 10.1111/j.14710307.2009.00498.x

Batakliev, T., Georgiev, V., Anachkov, M., Rakovsky, S., and Zaikov, G. E. (2014). Ozone decomposition. Interdiscip. Toxicol. 7, 47-59. doi: 10.2478/intox-20140008

Baumann, A. R., Martin, S. E., and Feng, H. (2009). Removal of Listeria monocytogenes biofilms from stainless steel by use of ultrasound and ozone. J. Food Prot. 72, 1306-1309. doi: 10.4315/0362-028X-72.6. 1306

Beuchat, L. R. (2002). Ecological factors influencing survival and growth of human pathogens on raw fruits and vegetables. Microbes Infect. 4, 413-423. doi: 10. 1016/S1286-4579(02)01555- 1 the use of ozone can become a valid measure in the control of cross-contamination by these bacteria in the food chain. Keeping under control the possible risks for operators and the process parameters, it might be possible to use this strategy as a complement/alternative to conventional sanitization processes, with clear advantages related to environmental impact reduction.

\section{AUTHOR CONTRIBUTIONS}

MM did conception and design of the work, analysis and interpretation of data, and revising the manuscript. MiM did conception and design of the work, analysis and interpretation of the data, and drafting and revising the manuscript. $\mathrm{AB}$ did carrying out of microbiological tests and treatments, and revising the manuscript. NI did design of the work, statistical analysis and interpretation of the data, and revising the manuscript.

\section{ACKNOWLEDGMENTS}

The authors are particularly grateful to Electrolux Italia and to $\mathrm{O}_{3}$ Technology for their technical support.

\section{SUPPLEMENTARY MATERIAL}

The Supplementary Material for this article can be found online at: https://www.frontiersin.org/articles/10.3389/fmicb. 2018.02024/full\#supplementary-material

Bräutigam, K. R., Jörissen, J., and Priefer, C. (2014). The extent of food waste generation across EU-27: Different calculation methods and the reliability of their results. Waste Manage. Res. 32, 683-694. doi: 10.1177/0734242X1454 5374

Brodowska, A. J., Nowak, A., Kondratiuk-Janyska, A., Piątkowski, M., and Śmigielski, K. (2017). Modelling the ozone-based treatments for inactivation of microorganisms. Int. J. Environ. Res. Public Health 14:1196. doi: 10.3390/ ijerph14101196

Carpentier, B., and Cerf, O. (1993). Biofilms and their consequences, with particular reference to hygiene in the food industry. J. Appl. Bacteriol. 75, 499-511. doi: 10.1111/j.1365-2672.1993.tb01587.x

Chang, L., and Craik, S. (2012). Laboratory simulation of the effect of ozone and monochloramine on biofilms in drinking water mains. Ozone Sci. Eng. 34, 243-251. doi: 10.1080/01919512.2012.686864

Chen, C.-W., Su, A., Yeh, C.-C., Yu, J.-W., Lu, Y.-T., and Jung, G.-B. (2016). Electrochemical generation of ozone: comparison of $\mathrm{IrO} 2$ series with $\mathrm{Pt} / \mathrm{SnO} 2$ anode support in solid membrane cell. Int. J. Electrochem. Sci. 11, 3351-3363. doi: 10.20964/100624

Clauditz, A., Resch, A., Wieland, K. P., Peschel, A., and Götz, F. (2006). Staphyloxanthin plays a role in the fitness of Staphylococcus aureus and its ability to cope with oxidative stress. Infect. Immun. 74, 4950-4953. doi: 10.1128/ IAI.00204-06

Corcoran, M., Morris, D., De Lappe, N., O’Connor, J., Lalor, P., Dockery, P., et al. (2014). Commonly used disinfectants fail to eradicate Salmonella enterica biofilms from food contact surface materials. Appl. Environ. Microbiol. 80, 1507-14. doi: 10.1128/AEM.03109-13

Cullen, P. J., and Norton, T. (2012). "Ozone sanitisation in the food industry," in Ozone in Food Processing, eds R. G. R. Colm O’Donnell, B. K. Tiwari, and P. J. Cullen (Oxford: Wiley-Blackwell), 163-176. doi: 10.1002/97811183074 72.ch 10 
de Candia, S., Morea, M., and Baruzzi, F. (2015). Eradication of high viable loads of Listeria monocytogenes contaminating food-contact surfaces. Front. Microbiol. 6:733. doi: 10.3389/fmicb.2015.00733.

Di Bonaventura, G., Piccolomini, R., Paludi, D., D’Orio, V., Vergara, A., Conter, M., et al. (2008). Influence of temperature on biofilm formation by Listeria monocytogenes on various food-contact surfaces: relationship with motility and cell surface hydrophobicity. J. Appl. Microbiol. 104, 1552-1561. doi: 10.1111/j. 1365-2672.2007.03688.x

Di Ciccio, P., Ghidini, S., Zanardi, E., Borrello, S., Vergara, A., Festino, A., et al. (2014). Effects of gaseous ozone on food-borne pathogens. Ital. J. Food Sci. 26, $116-118$.

Dosti, B., Guzel-Seydim, Z., and Greene, A. K. (2005). Effectiveness of ozone, heat and chlorine for destroying common food spoilage bacteria in synthetic media and biofilms. Int. J. Dairy Technol. 58, 19-24. doi: 10.1111/j.1471-0307.2005. 00176.x

Dourou, D., Beauchamp, C. S., Yoon, Y., Geornaras, I., Belk, K. E., Smith, G. C., et al. (2011). Attachment and biofilm formation by Escherichia coli O157:H7 at different temperatures, on various food-contact surfaces encountered in beef processing. Int. J. Food Microbiol. 149, 262-268. doi: 10.1016/j.ijfoodmicro. 2011.07.004

ECDC (2016). Infectious Disease Surveillance Summary, 2014 data. Stockholm: ECDC.

EFSA (2017). The European Union summary report on trends and sources of zoonoses, zoonotic agents and food-borne outbreaks in 2016. EFSA J. 15:5077. doi: 10.2903/j.efsa.2017.5077

Ercoli, L., Gallina, S., Nia, Y., Auvray, F., Primavilla, S., Guidi, F., et al. (2017). Investigation of a staphylococcal food poisoning outbreak from a chantilly cream dessert, in Umbria (Italy). Foodbor. Pathog. Dis. 14, 407-413. doi: 10. 1089/fpd.2016.2267

Fatemi, P., and Frank, J. F. (1999). Inactivation of Listeria monocytogenes/Pseudomonas biofilms by peracid sanitizers. J. Food Prot. 62, 761-765. doi: 10.4315/0362-028X-62.7.761

Ferreira, A., O'Byrne, C. P., and Boor, K. J. (2001). Role of $\sigma B$ in heat, ethanol, acid, and oxidative stress resistance and during carbon starvation in Listeria monocytogenes. Appl. Environ. Microbiol. 67, 4454-4457. doi: 10.1128/AEM.67. 10.4454-4457.2001

Ferreira, V., Wiedmann, M., Teixeira, P., and Stasiewicz, M. J. (2014). Listeria monocytogenes persistence in food-associated environments: epidemiology, strain characteristics, and implications for public health. J. Food Prot. 77, 150-170. doi: 10.4315/0362-028X.JFP-13-150

Geeraerd, A. H., Herremans, C. H., and Van Impe, J. F. (2000). Structural model requirements to describe microbial inactivation during a mild heat treatment. Int. J. Food Microbiol. 59, 185-209. doi: 10.1016/S0168-1605(00)00362-7

Geeraerd, A. H., Valdramidis, V. P., and Van Impe, J. F. (2005). GInaFiT, a freeware tool to assess non-log-linear microbial survivor curves. Int. J. Food Microbiol. 102, 95-105. doi: 10.1016/j.ijfoodmicro.2004.11.038

Gelman, A., Sachs, O., Khanin, Y., Drabkin, V., and Glatman, L. (2005). Effect of ozone pretreatment on fish storage life at low temperatures. J. Food Prot. 68, 778-784. doi: 10.4315/0362-028X-68.4.778

Gilbert, P., Evans, D. J., Evans, E., Duguid, I. G., and Brown, M. R. W. (1991). Surface characteristics and adhesion of Escherichia coli and Staphylococcus epidermidis. J. Appl. Bacteriol. 71, 72-77. doi: 10.1111/j.1365-2672.1991. tb04665.x

Giltner, C. L., Van Schaik, E. J., Audette, G. F., Kao, D., Hodges, R. S., Hassett, D. J., et al. (2006). The Pseudomonas aeruginosa type IV pilin receptor binding domain functions as an adhesin for both biotic and abiotic surfaces. Mol. Microbiol. 59, 1083-1096. doi: 10.1111/j.1365-2958.2005. 05002.x

Guo, Z., and Wang, Q. (2017). Efficacy of ozonated water against Erwinia carotovora subsp. carotovora in Brassica campestris ssp. chinensis. Ozone Sci. Eng. 39, 127-136. doi: 10.1080/01919512.2016.1270744

Güzel-Seydim, Z., Bever, P. I., and Greene, A. K. (2004). Efficacy of ozone to reduce bacterial populations in the presence of food components. Food Microbiol. 21, 475-479. doi: 10.1016/j.fm.2003.10.001

Honda, Y., Ivandini, T. A., Watanabe, T., Murata, K., and Einaga, Y. (2013). An electrolyte-free system for ozone generation using heavily boron-doped diamond electrodes. Diam. Relat. Mater. 40, 7-11. doi: 10.1016/j.diamond.2013. 09.001
Jofré, A., Aymerich, T., Grèbol, N., and Garriga, M. (2009). Efficiency of high hydrostatic pressure at $600 \mathrm{MPa}$ against food-borne microorganisms by challenge tests on convenience meat products. LWT - Food Sci. Technol. 42, 924-928. doi: 10.1016/j.lwt.2008.12.001

Jullien, C., Bénézech, T., Carpentier, B., Lebret, V., and Faille, C. (2003). Identification of surface characteristics relevant to the hygienic status of stainless steel for the food industry. J. Food Eng. 56, 77-87. doi: 10.1016/S02608774(02)00150-4

Kim, J. G., Yousef, A. E., and Dave, S. (1999). Application of ozone for enhancing the microbiological safety and quality of foods: a review. J. Food Prot. 62, 1071-1087. doi: 10.4315/0362-028X-62.9.1071

Ku, Y., Su, W. J., and Shen, Y. S. (1996). Decomposition kinetics of ozone in aqueous solution. Ind. Eng. Chem. Res. 35, 3369-3374. doi: 10.1021/ie9503959

Lemos, M., Gomes, I., Mergulhão, F., Melo, L., and Simões, M. (2015). The effects of surface type on the removal of Bacillus cereus and Pseudomonas fluorescens single and dual species biofilms. Food Bioprod. Process. 93, 234-241. doi: 10. 1016/j.fbp.2014.08.009

Liu, Y. J., Xie, J., Zhao, L. J., Qian, Y. F., Zhao, Y., and Liu, X. (2015). Biofilm formation characteristics of Pseudomonas lundensis isolated from meat. J. Food Sci. 80, M2904-M2910. doi: 10.1111/1750-3841.13142

Lundén, J. M., Miettinen, M. K., Autio, T. J., and Korkeala, H. J. (2000). Persistent Listeria monocytogenes strains show enhanced adherence to food contact surface after short times. J. Food Prot. 63, 1204-1207. doi: 10.4315/0362-028X63.9.1204

Maifreni, M., Frigo, F., Bartolomeoli, I., Buiatti, S., Picon, S., and Marino, M. (2015). Bacterial biofilm as a possible source of contamination in the microbrewery environment. Food Control 50, 809-814. doi: 10.1016/j.foodcont. 2014.10.032

Marino, M., Bersani, C., and Comi, G. (2001). Impedance measurements to study the antimicrobial activity of essential oils from Lamiaceae and Compositae. Int. J. Food Microbiol. 67, 187-195. doi: 10.1016/S0168-1605(01)00447-0

Marino, M., Frigo, F., Bartolomeoli, I., and Maifreni, M. (2011). Safety-related properties of staphylococci isolated from food and food environments. J. Appl. Microbiol. 110, 550-561. doi: 10.1111/j.1365-2672.2010.04909.x

Marino, M., Segat, A., Maifreni, M., Frigo, F., Sepulcri, C., and Innocente, N. (2015). Efficacy of ozonation on microbial counts in used brines forcheesemaking. Int. Dairy J. 50, 9-14. doi: 10.1016/j.idairyj.2015.06.003

Martinelli, M., Giovannangeli, F., Rotunno, S., Trombetta, C. M., and Montomoli, E. (2017). Water and air ozone treatment as an alternative sanitizing technology. J. Preven. Med. Hyg. 58, E48-E52. doi: 10.15167/24214248/jpmh2017.58.1.757

Martino, M. E., Maifreni, M., Marino, M., Bartolomeoli, I., Carraro, L., Fasolato, L., et al. (2013). Genotypic and phenotypic diversity of Pediococcus pentosaceus strains isolated from food matrices and characterisation of the penocin operon. Antonie van Leeuwenhoek 103, 1149-1163. doi: 10.1007/s10482-0139897-1

Mosteller, T. M., and Bishop, J. R. (1993). Sanitizer efficacy against attached bacteria in a milk biofilm. J. Food Prot. 56, 34-41. doi: 10.4315/0362-028X-56.1.34

Muhterem-Uyar, M., Dalmasso, M., Bolocan, A. S., Hernandez, M., Kapetanakou, A. E., Kuchta, T., et al. (2015). Environmental sampling for Listeria monocytogenes control in food processing facilities reveals three contamination scenarios. Food Control 51, 94-107. doi: 10.1016/j.foodcont.2014.10.042

Nicholas, R., Dunton, P., Tatham, A., and Fielding, L. (2013). The effect of ozone and open air factor on surface-attached and biofilm environmental Listeria monocytogenes. J. Appl. Microbiol. 115, 555-564. doi: 10.1111/jam.12239

Nielsen, C. K., Subbiahdoss, G., Zeng, G., Salmi, Z., Kjems, J., Mygind, T., et al. (2018). Antibacterial isoeugenol coating on stainless steel and polyethylene surfaces prevents biofilm growth. J. Appl. Microbiol. 124, 179-187. doi: 10.1111/ jam. 13634

Norwood, D. E., and Gilmour, A. (1999). Adherence of Listeria monocytogenes strains to stainless steel coupons. J. Appl. Microbiol. 86, 576-582. doi: 10.1046/j. 1365-2672.1999.00694.x

O’Donnell, C., Tiwari, B. K., Cullen, P. J., and Rice, R. G. (2012). "Status and trends of ozone in food processing," in Ozone in Food Processing, eds C. O’Donnell, B. K. Tiwari, P. J. Cullen, and R. G. Rice (Hoboken, NJ: Blackwell Publishing Ltd.). doi: 10.1002/9781118307472

Ölmez, H., and Akbas, M. Y. (2009). Optimization of ozone treatment of fresh-cut green leaf lettuce. J. Food Eng. 90, 487-494. doi: 10.1016/j.jfoodeng.2008.07.026 
Otero, V., Becerril, R., Santos, J. A., Rodríguez-Calleja, J. M., Nerín, C., and GarcíaLópez, M. L. (2014). Evaluation of two antimicrobial packaging films against Escherichia coli O157: $\mathrm{H} 7$ strains invitro and during storage of a Spanish ripened sheep cheese (Zamorano). Food Control 42, 296-302. doi: 10.1016/j.foodcont. 2014.02.022

Park, J. S., Choi, H., and Cho, J. (2004). Kinetic decomposition of ozone and para-chlorobenzoic acid (pCBA) during catalytic ozonation. Water Res. 38, 2284-2291. doi: 10.1016/j.watres.2004.01.040

Pascual, A., Llorca, I., and Canut, A. (2007). Use of ozone in food industries for reducing the environmental impact of cleaning and disinfection activities. Trends Food Sci. Technol. 18, 29-35. doi: 10.1016/j.tifs.2006.10.006

Patel, R. (2005). Biofilms and antimicrobial resistance. Clin. Orthop. Relat. Res. 437, 41-47. doi: 10.1097/01.blo.0000175714.68624.74

Pinto, L., Caputo, L., Quintieri, L., de Candia, S., and Baruzzi, F. (2017). Efficacy of gaseous ozone to counteract postharvest table grape sour rot. Food Microbiol. 66, 190-198. doi: 10.1016/j.fm.2017.05.001

Rajmohan, S., Dodd, C. E. R., and Waites, W. M. (2002). Enzymes from isolates of Pseudomonas fluorescens involved in food spoilage. J. Appl. Microbiol. 93, 205-213. doi: 10.1046/j.1365-2672.2002.01674.x

Rodrigues, D., Cerca, N., Teixeira, P., Oliveira, R., Ceri, H., and Azeredo, J. (2011). Listeria monocytogenes and Salmonella enterica biofilms susceptibility to different disinfectants and stress-response and virulence gene expression of surviving cells. Microb. Drug Resist. 17, 181-189. doi: 10.1089/mdr.2010.0183

Rossoni, E. M. M., and Gaylarde, C. C. (2000). Comparison of sodium hypochlorite and peracetic acid as sanitising agents for stainless steel food processing surfaces using epifluorescence microscopy. Int. J. Food Microbiol. 61, 81-85. doi: 10. 1016/S0168-1605(00)00369-X

Saha, R., Saha, N., Atwain, A., and Donofrio, R. S. (2014). Evaluation of disinfection efficacy of ozone and chlorinated disinfectant against the biofilm of Klebsiella michiganensis and Pseudomonas aeruginosa. Ann. Microbiol. 64, 1607-1613. doi: 10.1007/s13213-014-0804-4

Sankaran, S., Khanal, S. K., Pometto, A. L., and van Leeuwen, J. (Hans). (2008). Ozone as a selective disinfectant for nonaseptic fungal cultivation on cornprocessing wastewater. Bioresour. Technol. 99, 8265-8272. doi: 10.1016/j. biortech.2008.03.055

Scallan, E., Hoekstra, R. M., Angulo, F. J., Tauxe, R. V., Widdowson, M. A., Roy, S. L., et al. (2011). Foodborne illness acquired in the United States-Major pathogens. Emerg. Infect. Dis. 17, 7-15. doi: 10.3201/eid1701.P11101

Segat, A., Biasutti, M., Iacumin, L., Comi, G., Baruzzi, F., Carboni, C., et al. (2014). Use of ozone in production chain of high moisture Mozzarella cheese. LWT - Food Sci. Technol. 55, 513-520. doi: 10.1016/j.lwt.2013.10.029

Segat, A., Misra, N. N., Cullen, P. J., and Innocente, N. (2015). Atmospheric pressure cold plasma (ACP) treatment of whey protein isolate model solution. Innov. Food Sci. Emerg. Technol. 29, 247-254. doi: 10.1016/j.ifset.2015. 03.014

Segat, A., Misra, N. N., Cullen, P. J., and Innocente, N. (2016). Effect of atmospheric pressure cold plasma (ACP) on activity and structure of alkaline phosphatase. Food Bioprod. Process. 98, 181-188. doi: 10.1016/j.fbp.2016.01.010

Srikanth, A., Sathish, M., and Sri Harsha, A. (2013). Application of ozone in the treatment of periodontal disease. J. Pharm. Bioallied Sci. 5:89. doi: 10.4103/ 0975-7406.113304
Stellato, G., De Filippis, F., La Storia, A., and Ercolini, D. (2015). Coexistence of lactic acid bacteria and potential spoilage microbiota in a dairy processing environment. Appl. Environ. Microbiol. 81, 7893-7904. doi: 10.1128/AEM. 02294- 15

Takahashi, H., Miya, S., Igarashi, K., Suda, T., Kuramoto, S., and Kimura, B. (2009). Biofilm formation ability of Listeria monocytogenes isolates from raw ready-to-eat seafood. J. Food Prot. 72, 1476-1480. doi: 10.4315/0362-028X-72. 7.1476

Tapp, C., and Rice, R. G. (2012). "Generation and control of ozone," in Ozone in Food Processing, ed. R. G. R. Colm O’Donnell, B. K. Tiwari, P. J. Cullen (Oxford: Wiley-Blackwell), 33-54. doi: 10.1002/9781118307472.ch4

Thyberg, K. L., and Tonjes, D. J. (2016). Drivers of food waste and their implications for sustainable policy development. Resour. Conserv. Recycl. 106, 110-123. doi: 10.1016/j.resconrec.2015.11.016

Tiwari, B. K., and Rice, R. G. (2012). "Regulatory and legislative issues," in Ozone in Food Processing, eds R. G. R. Colm O'Donnell, B. K. Tiwari, and P. J. Cullen (Oxford: Wiley-Blackwell), 7-17. doi: 10.1002/9781118307472.ch2

To, M. S., Favrin, S., Romanova, N., and Griffiths, M. W. (2002). Postadaptational resistance to benzalkonium chloride and subsequent physicochemical modifications of Listeria monocytogenes. Appl. Environ. Microbiol. 68, 5258-5264. doi: 10.1128/AEM.68.11.5258-5264.2002

Tremoulet, F., Duche, O., Namane, A., Martinie, B., and Labadie, J. (2002). A proteomic study of Escherichia coli O157:H7 NCTC 12900 cultivated in biofilm or in planktonic growth mode. FEMS Microbiol. Lett. 215, 7-14. doi: 10.1016/S0378-1097(02)00879-0

Valdramidis, V. P., Cullen, P. J., and Tiwari, B. K. (2012). "Modelling approaches for ozone processing," in Ozone in Food Processing, eds R. G. R. Colm O’Donnell, B. K. Tiwari, and P. J. Cullen (Oxford: Wiley-Blackwell), 241-263. doi: 10.1002/9781118307472.ch14

Vatanyoopaisarn, S., Nazli, A., Dodd, C. E. R., Rees, C. E. D., and Waites, W. M. (2000). Effect of flagella on initial attachment of Listeria monocytogenes to stainless steel. Appl. Environ. Microbiol. 66, 860-863. doi: 10.1128/AEM.66.2. 860-863.2000

Williams, D. L., Woodbury, K. L., Haymond, B. S., Parker, A. E., and Bloebaum, R. D. (2011). A modified CDC biofilm reactor to produce mature biofilms on the surface of PEEK membranes for an in vivo animal model application. Curr. Microbiol. 62, 1657-1663. doi: 10.1007/s00284-011-9908-2

Wimpenny, J., Manz, W., and Szewzyk, U. (2000). Heterogeneity in biofilms. FEMS Microbiol. Rev. 24, 661-671. doi: 10.1111/j.1574-6976.2000.tb00565.x

Conflict of Interest Statement: The authors declare that the research was conducted in the absence of any commercial or financial relationships that could be construed as a potential conflict of interest.

Copyright (C) 2018 Marino, Maifreni, Baggio and Innocente. This is an open-access article distributed under the terms of the Creative Commons Attribution License (CC BY). The use, distribution or reproduction in other forums is permitted, provided the original author(s) and the copyright owner(s) are credited and that the original publication in this journal is cited, in accordance with accepted academic practice. No use, distribution or reproduction is permitted which does not comply with these terms. 